\title{
Vietnamese Enterprises: Current Issues of Technology Transfer
}

\author{
Tran Thi Bich Ngoc \\ School of Economics and Management \\ Hanoi University of Science and Technology, HUST \\ Hanoi, Vietnam \\ Bichngoc2201@gmail.com
}

\author{
Barysheva Galina Anzelmovna \\ International Scientific Educational Laboratory for the \\ improvement of wellbeing technologies of older adults \\ Tomsk Polytechnic University, TPU \\ Tomsk, Russia \\ ganb@tpu.ru
}

\begin{abstract}
The process of globalization and economic integration nowadays sharply intensifies economic competition in the field of production and services. Technological development is considered as the key to stimulating sustainable economic growth. In Vietnam, statistics show that most enterprises still use medium and backward technologies. Therefore, the products labeled "Made in Vietnam" are hard to compete in global market. In order to make a change, Vietnamese enterprises need to improve technology, including technology transfer, which is the solution to improve quality of the goods production and services, and to improve competitiveness of enterprises in general. In this study, the current consequence of technology transfer of Vietnamese enterprises is reviewed and some recommendations are suggested for further technological development and problem solving.
\end{abstract}

Keywords-Technological development; Technology transfer; patent; Invention; Utility solution

\section{INTRODUCTION}

Nowadays, technological progress has a positive impact on economic growth and human society [1]. Krume Nikoloski (2016) in his study of the relationship between technology and economic development concluded that important factors affecting economic growth are natural resources, human capital, capital information, technological development and socialpolitical conditions [2]. Among these factors, technological development plays an essential role in promoting economic growth and creates continuous opportunities for its further progress.

Economic growth has always been connected to technological development, which is proved by the nature of research and development (R\&D) efforts that drive productivity growth [3]. This relationship in Vietnam has been also evidenced by the statistics.

The data in Fig. 1 shows the trend of technological development in parallel with GDP growth. By 2015, the invention applications, patents and GDP have increased respectively by 176 per cent, 185 per cent and 336 per cent comparing to those in 2007.

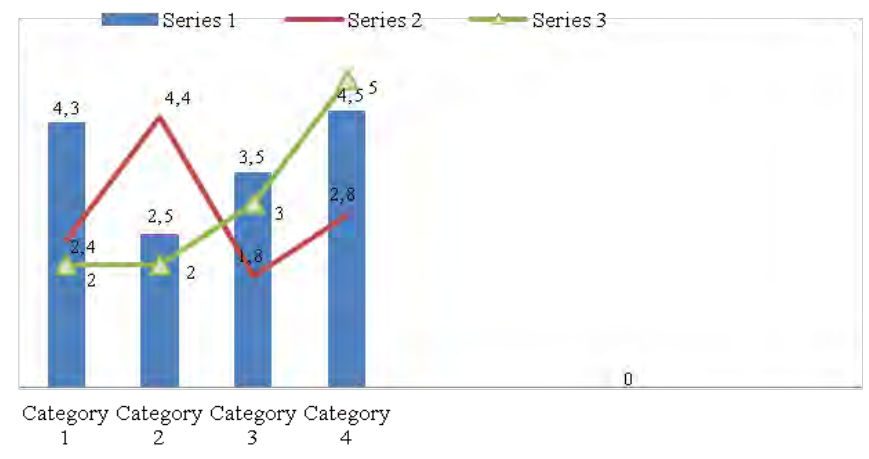

Fig. 1. Economic growth and intellectual property tendency in the period 2007-2015 (GDP in trillion VND). Source: National Office of Intellectual Property of Viet Nam (NOIP), Anual Intellectual Property Report 2015; GDP source from General Statistics Office (GSO), Vietnam.

In Vietnam, technological level is still trivial comparing with other countries in the region. One of the evaluation criteria for technological level is the Environmental Performance Index (EPI). EPI ranks countries' performance on high-priority environmental issue in two areas: protection of human health and protection of ecosystems.

Among the ASEAN' countries Vietnam EPI ranking in 2014, 2016 and 2018 is low in comparison with Singapore, Malaysia, Philippines and Thailand (Table 1). This is the consequence of backward technology that causes the environmental pollution in Vietnam. The other indicator representing technological level is Global Competitiveness Index (GCI). The Global Competitiveness Report 2017-2018 assesses the competitiveness of 137 economies. Even though Vietnam impressively increased 5 ranks from last year and 20 ranks from five years ago, in this period, with the rank of 55th place, it is still lower than other countries in the region such as Indonesia (36th), Thailand (32th) and Malaysia (23th) [4]. Among the subindexes, technological readiness (ranked 79) is one of the indicators that directly assesses the competitiveness of Vietnamese economy and reflects the adaptation of an economy to technologies in order to improve business 
performance and emphasize the ability to absorb new technologies.

TABLE I. ENVIRONMENT PERFORMANCE INDEX RANKINGS OF SOME ASIAN COUNTRIES

\begin{tabular}{|l|l|l|l|}
\hline \multicolumn{1}{|c|}{ Country } & \multicolumn{1}{c|}{$\mathbf{2 0 1 4}$} & \multicolumn{1}{c|}{$\mathbf{2 0 1 6}$} & \multicolumn{1}{c|}{$\mathbf{2 0 1 8}$} \\
\hline Japan & $26 / 178^{\text {a. }}$ & $39 / 180^{\text {a. }}$ & $19 / 180^{\text {a. }}$ \\
\hline South Korea & 43 & 80 & 60 \\
\hline China & 118 & 109 & 120 \\
\hline Singapore & 4 & 14 & 49 \\
\hline Malaysia & 51 & 63 & 75 \\
\hline Philippines & 114 & 66 & 82 \\
\hline Thailand & 78 & 91 & 121 \\
\hline Vietnam & 136 & 131 & 132 \\
\hline Indonesia & 112 & 107 & 133 \\
\hline Myanmar & 164 & 153 & 138 \\
\hline Cambodia & 145 & 146 & 150 \\
\hline Laos & 127 & 148 & 153 \\
\hline
\end{tabular}

Source: Environmental Performance Index Rankings 2014, 2016, 2018.

The technological level of Vietnamese enterprises is a matter of concern. According to the results of the 2016 Enterprise Survey conducted by the GSO and the Vietnam Chamber of Commerce and Industry (VCCI) in 10 industries, 60 per cent of enterprises are using technology that is over 6 years of age. Moreover, 65 per cent of these technologies originated from developing countries, of which 26.6 per cent of technology used by Vietnamese enterprises came from China. The proportion of technologies originating in developed countries such as the United States, Korea, Japan or the EU is only about 32 per cent, of which over 18 per cent of using technologies are from before 2005 [5].

Therefore, technological renovation and competitiveness are requirements and vital issues for every Vietnamese enterprise and the entire economy in general, that gives the chance to join the global value chain in the context of economic globalization. Today, there is a technological gap between developed and developing countries. Developing countries, those are lack of STI and dependant on developed countries, still have to import modern equipment and technology from countries with more developed technology[2].

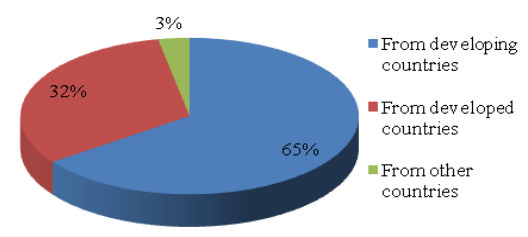

Fig. 2. The proportion of technology transferred by Vietnamese enterprises from other countries. Source: [5]

\section{RESEARCH METHOD AND MATERIALS}

In this study, authors use comparative research methodology and provide evidence to determine the position of Vietnam on global map of technology and the important role and indispensableness of technology and technology transfer (TT) in socio-economic development. The current status of science, technology and innovation (STI) activities is described to address the ranking and real abilities of Vietnamese researchers and the effectiveness of $R \& D$ in Vietnam, which are considered as the cause of the need for TT. In many cases, the author uses statistical analysis methods in comparison with Singapore, Thailand and some other countries in the region to assure the given statements. The lack of relationship between Vietnamese research institutes, universities and enterprises is studied based on the number of patents applied in practice. The study also addresses issues, which enterprises are facing in TT activities through the statistical data and survey results.

The statistical data and materials used in the article are taken from reliable national and international sources of information; objective evidences are cited from official articles, research works, surveys and other statistics documents published in Vietnam and other countries.

\section{ReSEARCH PROBLEMS AND RESUlts}

TT refers to the transition of know-how, skills, technical knowledge or technology from one organizational setting to another [6]. Yooduk Juna and Ilyong Jib defined that TT has been frequently paired with "technology commercialization", and for this reason TT has occasionally been understood as a sub-part of the latter [7]. Fundamentally, commercialization is the final stage of innovation process. It transforms technology and technique received from innovation activities into a product or process that will gain market acceptance and adoption [8]. Commercialization can also be understood as the process of buying and selling technology, and/or new process, production organization, new marketing and sale methods acquired through the first two phases of innovation process (R\&D) to obtain profit [9].

The reality indicates that technological development of Vietnamese enterprises is mainly in two forms: developing their own technology and/or receiving from external source of technology. There are many factors affecting enterprises technology development, and they can be classified into internal and external factors.

\section{A. Internal factors}

The Internal factors are the inside problems existed in the enterprise. That is the ability to develop the necessary technology itself.

Nevertheless, we consider that this ability is very low due to the following reasons:

- Most Vietnamese enterprises are small and medium enterprises (SMEs) which do not have or have insignificant scientific and technical staffs involving in STI activities; 
Poor awareness of the importance of innovation activities;

- Deficiency of scientific and technical personals, and their limited ability to participate in STI activities and TT;

- Low financial capacity.

The internal factors mentioned above are reflected in the practice of technological development and TT of Vietnamese enterprises. Like many other economies, Vietnamese SMEs (no more than 200 employees under the Law on Small and Medium-Sized Enterprise Support 2018) account for the vast majority. According to the official statistics of the GSO in 2017, the number of SMEs is 495,434, accounting for about 98 per cent of 505,059 acting enterprises [10]. The main STI activities of these enterprises are TT or goods production under license.

There are inadequacy of qualitativeness and quantitativeness of STI personals working in enterprises. According to the survey conducted in 2014, the R\&D personal of all qualification is 164,744 persons, of which only 14.4 per cent work in the firms (Fig. 3); nearly 85 per cent $(139,531$ persons) are occupied in public sector and 15 per cent $(20,917$ persons) - in private sector. This is unbalanced proportion whereas it is 70 per cent $(36,922$ persons $)$ and 30 per cent (14,256 persons) in Thailand [11], 46 per cent $(16,172$ persons) and 54 per cent $(18,816$ persons) in Singapore [12].

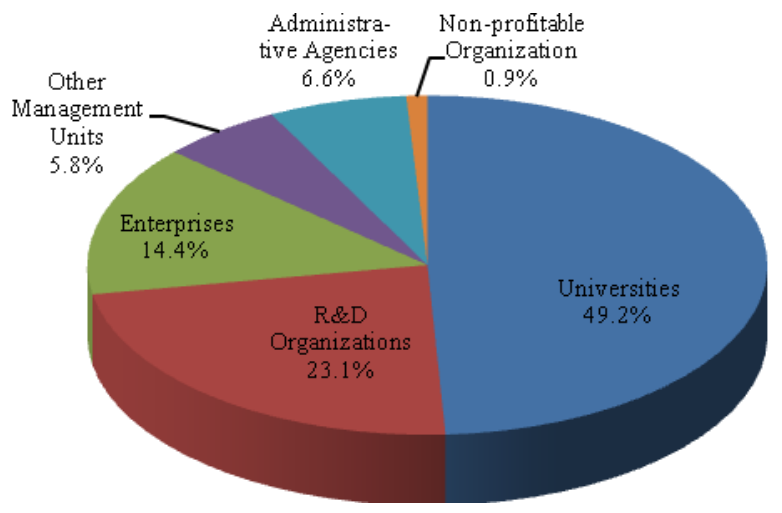

Fig. 3. Percentage of researchers by activity sectors. Source: [13]

A survey conducted by the Research Institute of Vietnam National University (VNU), Hanoi in 2015 shows that among 50 per cent of surveyed enterprises, the percentage of employees involved in STI accounts for only 6-10 per cent of the total employees [14]. The majority of Vietnamese entrepreneurs do not have clear awareness of the importance of technological innovation (Fig. 4). There are only 12 of 583 surveyed enterprises (2\%) which have R\&D department.

In the period 2010-2012, companies' expenditure on R\&D is highly insufficient. According to the above survey, only 4 per cent of enterprises spent more than 10 billion VND on innovation-related activities, 49 per cent - from 1 to 3 billion
VND and 33 per cent - less than 500 million VND. The main costs are payment for TT and consultancy [15].

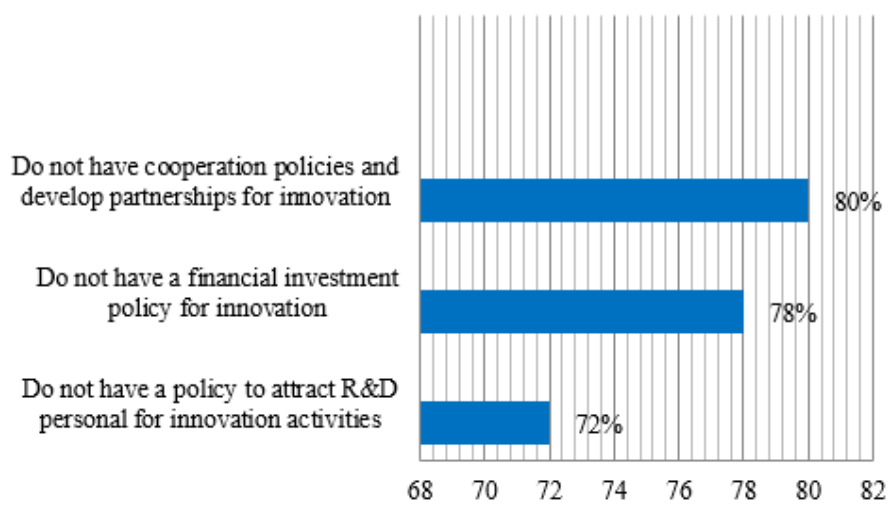

Fig. 4. Understanding of Vietnamese entrepreneurs about innovation. Source: VBM, 2017

Those issues can be explained by the low financial potential of Vietnamese enterprises, as most of them (98 per cent) are SMEs and up to 99.47 per cent operate in the private sector. The enterprises of this type often find it difficult to access state financial support as they do not qualify for subsidized loans or have not enough assets to get mortgage loan from the banks.

TABLE II. NUMBER OF ACTING ENTERPRISES AS OF 31 DECEMBER 2016 BY CAPITAL SIZE AND BY TYPE OF OWNERSHIP

\begin{tabular}{|l|l|l|l|l|}
\hline $\begin{array}{c}\text { Size of } \\
\text { capital (in } \\
\text { billion VND) }\end{array}$ & Total & $\begin{array}{c}\text { State owned } \\
\text { enterprises }\end{array}$ & $\begin{array}{c}\text { Non-state } \\
\text { enterprises }\end{array}$ & $\begin{array}{c}\text { Foreign } \\
\text { Invested } \\
\text { Enterprises }\end{array}$ \\
\hline Total & 505,059 & 2,662 & 488,395 & 14,002 \\
\hline Under 0.5 & 57,181 & 18 & 56,589 & 574 \\
\hline $\begin{array}{l}\text { From 0.5 to } \\
\text { under 1 }\end{array}$ & 53,662 & 2 & 53,223 & 437 \\
\hline $\begin{array}{l}\text { From 1 to } \\
\text { under 5 } 204,024\end{array}$ & 86 & 202,016 & 1,922 \\
\hline $\begin{array}{l}\text { From 5 to } \\
\text { under 10 }\end{array}$ & 69,773 & 99 & 68,347 & 1,327 \\
\hline $\begin{array}{l}\text { From 10 to } \\
\text { under 50 }\end{array}$ & 85,253 & 599 & 80,657 & 3,997 \\
\hline $\begin{array}{l}\text { From 50 to } \\
\text { under 200 }\end{array}$ & 23,638 & 701 & 19,836 & 3,101 \\
\hline $\begin{array}{l}\text { From 200 to } \\
\text { under 500 }\end{array}$ & 6,167 & 442 & 4,395 & 1,330 \\
\hline $\begin{array}{l}\text { From } \\
\text { and over }\end{array}$ & 5,361 & 715 & 3,332 & \multicolumn{1}{|c|}{ Source: [10, p.363-363]. } \\
\hline
\end{tabular}

The reality indicates that technological development of Vietnamese enterprises is mainly in two forms: developing their own technology and/or receiving from external source of technology. There are many factors affecting enterprises technology development, and they can be classified into internal and external factors. 


\section{B. External factors}

The external factor is the national and global technological abilities that meet technology needs of Vietnamese enterprises, and the weakness of the technology market in the country.

The deficiencies due to the characteristics of the enterprises restrict the technological self-development capability of Vietnamese enterprises. Therefore, TT here is an objective inevitability. Typically, enterprises receive technology from universities, research institutes and from other countries, but this type of TT seems to be occasional. The Vietnamese entrepreneurs and foreign - invested enterprises (FIEs) are the main subjects' carrying out TT from other countries to Vietnam. The data of The National Office of Intellectual Property of Vietnam (NOIP) evidences trends in TT (Table 3\&4).

The deficiencies due to the characteristics of the enterprises restrict the technological self-development capability of Vietnamese enterprises. Therefore, TT in this kind of firms is an objective inevitability. Normally, enterprises receive technology from universities, research institutes and from abroad. The Vietnamese entrepreneurs and foreign - invested enterprises carry out TT from other countries to Vietnam. The number of contracts in Tables $3 \& 4$ evidences trends in TT.

TABLE III. NUMBER OF REGISTERED LICENSING CONTRACTS IN 2006-2016

\begin{tabular}{|c|c|c|c|c|}
\hline \multirow{2}{*}{ Year } & \multicolumn{3}{|c|}{ Number of registered licensing contracts } \\
\cline { 2 - 5 } & Vietnamese - Vietnamese & Vietnamese - Foreigner & Foreigner - Foreigner & Total \\
\hline 2006 & $77(141)$ & $55(373)$ & $4(5)$ & $135(519)$ \\
\hline 2007 & $53(72)$ & $70(300)$ & $33(103)$ & $135(1190)$ \\
\hline 2008 & $132(260)$ & $76(477)$ & $24(146)$ & $163(622)$ \\
\hline 2009 & $74(98)$ & $65(387)$ & $16(71)$ & $145(617)$ \\
\hline 2010 & $69(147)$ & $60(399)$ & $25(156)$ & $143(510)$ \\
\hline 2011 & $64(73)$ & $54(281)$ & $8(208)$ & $142(575)$ \\
\hline 2012 & $89(198)$ & $45(169)$ & $9(45)$ & $164(341)$ \\
\hline 2013 & $109(152)$ & $46(144)$ & $22(166)$ & $216(815)$ \\
\hline 2014 & $90(188)$ & $104(461)$ & $23(106)$ & $203(969$ \\
\hline 2015 & $95(251)$ & $85(612)$ & $18(362)$ & $225(1057)$ \\
\hline 2016 & $118(240)$ & $89(455)$ & & \\
\hline
\end{tabular}

b. Figures in blanket are the numbers of licensed subject matters. Source: Accessed from NOIP Vietnam [16].

TABLE IV. NUMBER OF REGISTERED CONTRACTS ON PROPERTY RIGHT TRANSFER BY HOLDERS IN 2007-2016

\begin{tabular}{|c|c|c|c|c|}
\hline \multirow{2}{*}{ Year } & \multicolumn{4}{|c|}{ Number of registered assigned contracts on Property Rights Transfer } \\
\hline & Vietnamese - Vietnamese & Vietnamese - Foreigner & Foreigner - Foreigner & Total \\
\hline 2006 & $37(84)$ & $7(15)$ & $34(107$ & $78(206)$ \\
\hline 2007 & $237(670)$ & $18(38)$ & $199(461)$ & $454(1169)$ \\
\hline 2008 & $270(609)$ & $36(111)$ & $232(589)$ & $538(1309)$ \\
\hline 2009 & $604(1714)$ & $24(44)$ & $20(43)$ & $648(1801)$ \\
\hline 2010 & $304(696)$ & $69(214)$ & $203(505)$ & $576(1415)$ \\
\hline 2011 & $325(693)$ & $37(153)$ & $179(820)$ & $541(1666)$ \\
\hline 2012 & $357(700)$ & $31(87)$ & $206(908)$ & $594(1695)$ \\
\hline 2013 & $423(912)$ & $60(189)$ & $220(558)$ & $703(1659)$ \\
\hline 2014 & $456(1116)$ & $53(303)$ & $334(802)$ & $843(2221)$ \\
\hline 2015 & 492 (1413) & 49 (174) & 307 (827) & $848(2414)$ \\
\hline 2016 & 614 (1192) & $46(86)$ & $334(885)$ & $994(2163)$ \\
\hline
\end{tabular}

c. Figures in blanket are the numbers of assigned subject matters. Source: Accessed from NOIP Vietnam [15].

Technological capabilities of public research institutes and universities are considered as their ability to develop technology. Kenichi Hatori called technology transfer from universities and public research institutes to private companies as "academia-industry cooperation" [17]. In Vietnam, the ability to transfer technology from universities and research organizations to enterprises is limited. According to the NOIP, every year, nearly 2,000 science research projects are 
implemented by research organizations and another 16,000 20,000 by universities, but only 2,000 research results $(10$ per cent) could be useful to apply to the manufacturing and service sector with less applicable industrial solutions and inventions [18].

World Intellectual Property Organization (WIPO) data shows that in the period of 2007-2016, the total number of patent grants are 10,496, of which Vietnamese (residents) owned 459 (less than 4.37 per cent) the the remaining 9,918 (94.49 per cent) belongs to foreigners (Table 5).

TABLE V. NUMBER OF PATENT APPLICATIONS AND PATENT GRANTS IN 2007-2016

\begin{tabular}{|c|c|c|c|c|c|c|}
\hline \multirow[b]{2}{*}{ Year } & \multicolumn{2}{|c|}{ Resident } & \multicolumn{2}{|c|}{ Non -Resident } & \multicolumn{2}{|c|}{ Abroad } \\
\hline & 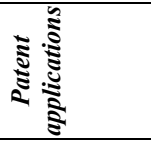 & 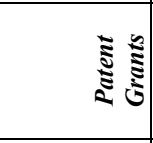 & 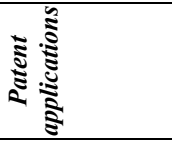 & 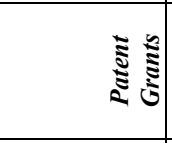 & 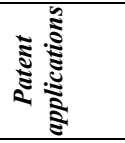 & 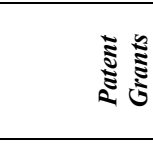 \\
\hline 2007 & 219 & 34 & 2,641 & 691 & 13 & NA \\
\hline 2008 & 204 & 39 & 1,995 & 627 & 14 & 2 \\
\hline 2009 & 258 & 29 & 2,632 & 677 & 6 & 2 \\
\hline 2010 & 306 & 29 & 3,276 & 793 & 19 & 4 \\
\hline 2011 & 300 & 42 & 3,260 & 958 & 22 & 5 \\
\hline 2012 & 382 & 52 & 3,423 & 1,016 & 44 & 4 \\
\hline 2013 & 442 & 59 & 3,552 & 1,123 & 54 & 11 \\
\hline 2014 & 487 & 36 & 3,960 & 1,361 & 74 & 24 \\
\hline 2015 & 582 & 63 & 4,451 & 1,325 & 100 & 25 \\
\hline 2016 & 560 & 76 & 4,668 & 1,347 & 73 & 42 \\
\hline Total & 3,740 & 459 & 33,858 & 9,918 & 419 & 119 \\
\hline
\end{tabular}

The analysis of data in Table 5 let know that the number of applications for patent has increased almost two-times from 2,873 in 2007 to 5,301 in 2016 , averaging nearly 18.5 per cent annually, but the ratio between the number of applications for patents and granted patents notably is less than that in Singapore. For example, Vietnam had 5,301 applications as of 2016, of which 1,465 were granted, achieving a performance rate of 27.63 per cent. Similarly, this proportion in Singapore has accounted for 62 per cent (Fig. 5). As a result, the R\&D of Vietnamese researchers is not effective.

These figures demonstrate the low capacity of R\&D of Vietnamese scientists that do not meet expectations and show the technology gap between Vietnam and the World. The promotion of innovation research in the country and the TT from other countries are inevitable in the current context of technology level in Vietnam.

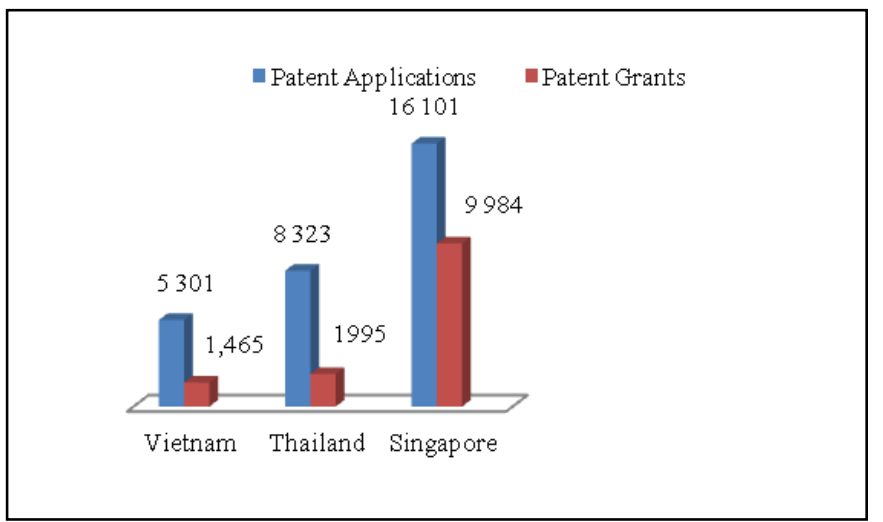

Fig. 5. Total number of Patent applications and Patent grants in Vietnam, Thailand and Singapore in 2016. Source: accessed from WIPO, 2018. Statistical Country Profiles

The data of Table 6 exposes the effectiveness of R\&D activities and the problems that require in-depth study: the proportion of granted utility solutions and inventions made by the public sector including universities and research institutes from 2011 to 2015 was 18.58 per cent, while the number of researchers working in these organizations accounted for 72.3 per cent of the total (Fig. 3). In the contrastive situation, Vietnamese enterprises, individuals and others have made 81.42 per cent of the total granted patents, while there were only 15 per cent of total researchers working in private sector. 
TABLE VI. PATENT GRANTED FOR VIETNAMESE UTILITY SOLUTIONS AND INVENTIONS OF VIETNAMESE BY HOLDER IN 5 YEARS 2011 -2015

\begin{tabular}{|c|c|c|c|c|c|c|c|c|c|c|}
\hline \multirow[b]{2}{*}{ 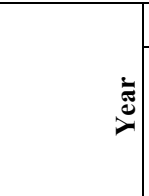 } & \multicolumn{2}{|c|}{ Others } & \multicolumn{2}{|c|}{ Individuals } & \multicolumn{2}{|c|}{ Enterprises } & \multicolumn{2}{|c|}{ Universi-ties } & \multicolumn{2}{|c|}{ Research Institutes } \\
\hline & 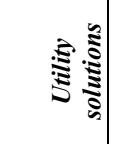 & 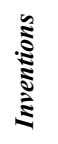 & 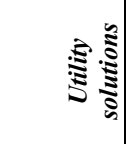 & 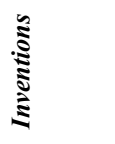 & 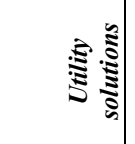 & 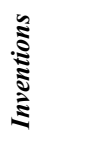 & 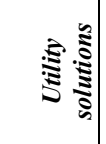 & 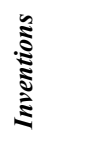 & 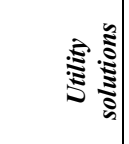 & 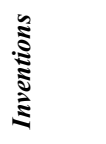 \\
\hline 2011 & 3 & 1 & 16 & 17 & 24 & 16 & 1 & 4 & 2 & 4 \\
\hline 2012 & 0 & 0 & 28 & 21 & 18 & 11 & 4 & 6 & 9 & 6 \\
\hline 2013 & 0 & 2 & 29 & 30 & 25 & 20 & 6 & 0 & 14 & 0 \\
\hline 2014 & 5 & 2 & 23 & 24 & 26 & 4 & 4 & 2 & 13 & 2 \\
\hline 2015 & 5 & 2 & 33 & 31 & 28 & 16 & 4 & 4 & 16 & 4 \\
\hline Total & 13 & 7 & 129 & 123 & 121 & 67 & 19 & 16 & 54 & 16 \\
\hline
\end{tabular}

Considering the above mentioned analysis we can conclude that the ability of TT from research institutes and universities to enterprises is limited. Conceivably, the causes could be:

1) The research works did not focus on key areas and priority projects; the effectiveness of R\&D is low;

2)The R\&D activities have not been linked to the reality of domestic production and business demands and do not grasp the technology requirements trends of manufacturing and service sectors, i.e. the relationship between the public research sector and enterprises is not tight;

3)Qualifications of research staff do not meet the requirements of $R \& D$.

Due to the weakness in technological development in the country, Vietnamese enterprises are being forced to receive technology from other countries. From 2010 to 2017, the number of registered contracts on licensing and property rights transfer between Vietnamese and foreigners accounted for 828 , and between FIEs and foreigners accounted for 1,577 [15]. However, large technological readiness level between recipient countries and investing countries, and limitation of financial capability slow down the process of TT. According to the Ministry of Science and Technology (MOST), there were only 115 contracts fully completed with total estimated value of VND 447,000 billion VND, in which 02 contracts on TT of Samsung Corporation in 2017 worth about 323,000 billion VND [19]. As a result, the success rate is slow.

We assert that FIEs play an important role in attracting and transferring technology. However, the efficiency of the TT implemented through FDI channels has not met expectations. The MOST' statistics reported that in 2012, the number of FDI projects using high technology in Vietnam is low in comparison with other countries. Only 5-6 per cent of FDI projects in Vietnam use advanced technology; over 80 per cent of FDI projects use average technology; and about 14 per cent of FDI enterprises use low and out-dated technology [20].

Technologies transferred under the FDI projects mainly serve the interests of investors, so it may lead to:

(a) the problem of environmental pollution, carbon emissions; (b) obstructing technological diffusion due to know-how protection;

and (c) highly defined technology value that is out of control of the State authorities and used by investor as method of "transfer pricing" (TP) between enterprises under common ownership.

Foreign investors try to use partner' import dependency on technology, materials and components as a way to evade income taxes. When making capital contributions with technology in investment projects, parent companies often declare technology or material with value higher than they really are. Then, the subsidiaries transfer that value to the parent company in the form of depreciation, creating real interest and fake losses to evade the corporation income tax payment annually. The same problems have occurred in Vietnam. For example, in Ho Chi Minh City, 90 per cent of FIEs operating in the textile and garment industry have unprofitable business report. However, these FIEs continue to invest in production expansion announcing losses in business. The case of Coca-Cola Vietnam is another example of suspicious TP. For more than 20 years of operation in Vietnam, until September 30, 2011 the Company continuously had reported on losses, which reached up to 3.768 billion VND (approximately 210 million US dollars), exceeded the initial investment capital (2,950 billion VND). Due to the claimed loss, Coca-Cola was exempt from corporation income tax in accordance with the Vietnam Legislation, but its income actually continues to grow at a rate of 20-30 per cent per year and the company plans to invest 300 million USD in new projects in Vietnam [21].

One of the reasons that affect the TT to enterprises is that the technology market in Vietnam has not yet developed. Man N.L. (2017) in his research "Technology Market Development in Vietnam" pointed out that the weakness of the technology market is caused by the following reasons:

(a) incomplete legal framework;

(b) the lack of knowledge from the Vietnamese enterprises about technology source;

(c) limitation of $\mathrm{R} \& \mathrm{D}$ results that may be transferred from research institutes and universities to enterprises; 

[22].

(d) undetermined true value of the $\mathrm{R} \& \mathrm{D}$ results ;

and (e) underdeveloped information and service systems

\section{RECOMMEDATIONS}

Recognizing the important role of technology development, the State has developed comprehensive solutions to address issues related to STI activities that have been institutionalized in the Laws and the Strategies, National Development Programs, such as:

- $\quad$ Law No. 07/2017/QH14 on Technology Transfer 2017;

- $\quad$ Law No. 29/2013/QH13 on Science and Technology;

- Law No.19/VBHN-VPQH on Intellectual Property 2013;

- $\quad$ Law No. 21/2008/QH12 on high technology 2008;

- Law No. 04/2017/QH14 on supporting small and medium-sized enterprises;

- Strategy for science and technology development in the 2011-2020;

- Industrial Development Strategy through 2025, vision toward 2035;

- National Technological Renovation Program up to 2020 , etc.

State policies create conditions and great opportunities for the technological development of the country and technological renovation for Vietnamese enterprises. However, there remain problems that have arisen when analyzing the internal and external factors, affecting TT. In this study, we suggest some solutions that may be useful to overcome inadequacies discovered in the enterprises' business practice.

1) Solving problems related to $R \& D$ human resource and the relationship between enterprises, $R \& D$ institutes and universities

- Restructuring science and technology human resources and attracting R\&D staffs into manufacturing sector;

- Encouraging the cooperation and creating regulatory environment for spin-off between enterprises, R\&D institutes and universities are the most common solutions by allowing a large number of researchers to join the researches and helping enterprises to absorb new technology;

- Providing knowledge of innovation for staffs of R\&D organizations to increase the effectiveness of research works; universalizing theory of innovation management for universities and colleges students;

- Encouraging international cooperation in science; consulting and assisting Vietnamese scientists to public their researches on international-standard publications.

\section{2) Funding for STI}

- Continuing to increase spending on STI activities as stated in The Strategy for Science and Technology Development for the period of 2011-2020: to reach Gross domestic expenditure on R\&D (GERD) of 1.5 per cent GDP in 2015 and over 2 per cent GDP in 2020, focusing on innovation projects. In the period 20112016, an average GERD was nearly 0.5-0.6 per cent GDP [19];

- Providing tax preference reserved for TT and import of research and production equipment as stated in different documents such as Law on High technology, Law on Intellectual property, Law on Investment, Law on supporting small and medium-sized enterprises;

- Supporting start-ups and other enterprises in financing innovation activities by the form of loan provision, credit guarantee, preferential corporate income tax, land rental preferences, technology renewal, training, counseling, or human resource development;

- Improving the accessibility of investment Funds established by the Government such as National Technology Innovation Fund, National Science and Technology Development Fund, Hi-tech Venture capital Fund.

- Attracting investment in enterprises' STI activities through venture capital funds and stock market; providing consult action and services for STI;

- Encouraging and supporting research funding for individuals participating in STI fields

3) Improving the access to Innovation resources

- Simplifying administrative procedures and clarifying financial requirements from support funds; facilitating enterprises to participate in national cooperation programs (science forums, technology fairs, international consultants, etc.);

- Completing system of legal documents Government policies related to STI;

4) Completing the database of Science and technology

- Building national database under The Circular 10/2017/TT-BKHCN on Science and Technology and Innovation; regularly update information about new technologies in Vietnam and around the World; facilitating enterprises and clients who are willing to access information about technology;

- Establishing a reporting regime for the STI output as part of the statistical report. 


\section{CONCLUSION}

Technology is the result of STI activity. The technological potential of the country depends on STI activities and plays an important role in the process of technological renovation and enhancing the competitiveness of enterprises. The National Technological Renovation Program up to 2020 targets that in $2020100 \%$ of enterprises will manufacture key products and national product and master the advanced production technology. The goal of the Strategy for Science and Technology Development for the 2011-2020 periods is that in 2020 hi-tech products and hi-tech application products will account for the value of $45 \%$ GDP. Reaching the targets requires sustained efforts of the state, scientists' and business community for technological development.

\section{REFERENCES}

[1] N. Bostroam, John Wiley, January 2007, pp. 129-152. DOI:10.1002/9780470165874.

[2] K. Nikoloski, "Technology and Economic Development: Retrospective. Journal of Process Management", New Technologies, International, vol. 4, No.4, 2016, pp. 45-50.

[3] De Loo, Ivo; Soete, Luc, "The Impact of Technology on Economic Growth: Some New Ideas and Empirical Considerations". Working paper, UN University, vol.18, 1999. Retrieved from: http://collections.unu.edu/view/UNU:1054.

[4] World Economic Forum, "The Global Competitiveness Report 20172018", Geneva, 2017, p. ix.

[5] Vietnam Center for Science and Technology Communication, "Formatting effective linkage model to develop science and technology market”. Retrieved from: https://www.most.gov.vn/vn/tintuc/14789/xay-dung-mo-hinh-lien-ket-hieu-qua-de-phat-trien-thi-truongkhcn.aspx (in Vietnamese).

[6] J. D. Roessner, "Technology Transfer", In: C. Hill, Ed., Science and Technology Policy in the US. A Time of Change, Longman, London, 2000.

[7] J. Yooduk, J. Ilyong, "Demand-pull Technology Transfer and NeedsArticulation of Users: A Preliminary Study". Procedia Computer Science. No. 91, 2016, pp. $287-295$.

[8] O. Osoro, S. Kirama, P. Vermeulen, "Factors Affecting Engagement and Commercialization Of Innovation Activities of Firms in Tanzania". Tanzanian Economic Review. Vol. 4 No. 1 \& 2, 2014, pp. 73-90.

[9] A. Zaretsky, T. Ivanova, "Industrial Technologies and Innovations". Textbook for high schools - The standard of the third generation. Petersburg, Russia, 2014, p 221.

[10] General Statistics Office Vietnam, "Statistical Yearbook 2017", Statistical publishing, Hanoi, 2018, p. 339.

[11] National Science Technology and Innovation Policy Office NSTIPO (NSTIPO), "Thailand Science Technology and Innovation Profile 2014", 2015, p. 17. Retrieved from: http://www.sti.or.th/apnisforum/download/THAILAND-STI-Profile2014.pdf.

[12] Agency for Science, Technology and Research, Singapore (A-SATR) "National Survey of R\&D in Singapore 2015", 2016, p 10. Retrieved from: https://www.astar.edu.sg/Portals/81/Data/News\%20And\%20Events/Publications/Natio nal\%20Survey\%20of\%20R\&D/Files/RnD\%202015.pdf.

[13] Ministry of Science and Technology, Vietnam, "Vietnam Science and Technology Outlook 2016", 2017, p. 10. Retrieved from: https://www.daad-

vietnam.vn/files/2017/03/01EN_GSD2017_MOST_P.B.-

Thach_Vietnam-ST-Outlook.pdf.

[14] Vietnam Business Monitoring, "The actual situation of innovation activities of Vietnamese enterprises", 2017. Retrieved from: http:// vibiz.vn/upload/17604/20171002/Tuan 40
ng_tao_cua_doanh_nghiep_Viet_Nam_Nhom_Ngan_hang_Yen__ T am.pdf.

[15] X. N. Phung, Q. Le, "Innovation of Vietnamese enterprises". Journal of Science, Economics and Business, Vietnam National University, vol. 29 (4), 2013, pp. 1-11 (in Vietnamese).

[16] National Office of Intellectual Property of Vietnam (NOIP), "Annual Report Of Intellectual Property Activities 2016", Science and Technics Publishing house, Hanoi, 2017, pp. 94-96.

[17] K. Hatori, "Technology Transfer By Public Research Organizations", Japan Patent Office - Asian-Pacific Industry Property Center Retrieved from:

https://www.jpo.go.jp/torikumi_e/kokusai_e/training/textbook/pdf/Tech nology_Transfer_by_Public_Research_Organizations.pdf.

[18] M. Thao, "Lack of engagement with businesses". E-portal of Vietnam National Assembly. Retrieved from: http://daibieunhandan.vn/default.aspx?tabid=156\&NewsId=314765 (in Vietnamese).

[19] Ministry of Science and Technology, Vietnam, "Report No. 589/BKHCN-VP, March, 12 th 2018 to The Vietnam National Assembly", 2018, p.2, $14 . \quad$ Retrieved from: http://quochoi.vn/UBTVQH/cacphienhop/quochoikhoaXIV/phienhopthu 22/Pages/default.aspx (in Vietnamese).

[20] T.H. Le, P.C. Le, "The patterns of inward FDI under the "Doi Moi" policy", Journal Vietnam Trade and Industry review online. Retrieved from: http://www.tapchicongthuong.vn/the-patterns-of-inward-fdiunder-the-doi-moi-policy-2018012410262775p0c488.htm Vietnamese).

[21] T.H. Nguyen, "Transfer pricing in Foreign Invested Enterprises: Current situation and Solutions". Finance Magazine, vol. 2 (623), December, 2015, p.17-20 (in Vietnamese).

[22] N. L. Man, "Technology Market Development in Vietnam", 2017. Retrieved from: http://anhminhcuong.vn/chuyen-kinh-doanh/ph-c3-alt20tri-e1-bb-83n-20th-e1-bb-8b-20tr-c6-b0-e1-bb-9dng-20c-c3-b4ng20ngh-e1-bb-87-20-e1-bb-9f-20vi-e1-bb-87t-20. 